\title{
Antecedents of Business Level Strategies in Nigerian Agro-Based Firms
}

\author{
- Ibidunni Ayodotun Stephen, Ogundana Oyebisi Mary
}

\begin{abstract}
The purpose of this paper is to investigate the impact of antecedent factors on business level strategies of Nigerian agro-based firms. The study made use of survey method over one hundred and ninety-three respondents. Pearson's correlation and regression analysis were used to analyze the data obtained. The existing relationship stemming from the results revealed that top management factor, organizational system, and departmental connectivity are important antecedent factors that determine the success or otherwise of strategic orientation dimensions. The study recommends that the calibre of the top management personnel and the internal cohesion between departments should be considered a critical variable in the adoption of particular orientation.
\end{abstract}

Keywords: Strategic Orientation, Business Level Strategies, Top Management Factor, Organizational System, Departmental Connectivity

JEL Classification: M10

\section{INTRODUCTION}

The dominance of oil as the main source of revenue in the economic landscape of Nigeria brought about a deliberate neglect of agriculture which had served as the highest employment generation sector accounting for about 50 per cent of employment and over 40 per cent of Nigeria's GDP. However, recent efforts by the government to strategically reposition the economy for greater gains suggested a transition and refocusing of the nation's agricultural sector as a key driver of the required national economic development. It is evident that anticipated gains from the agricultural sector will require minimizing present challenges. Empirical evidence indicate that the agriculture sector with a growth rate of about $5.1 \%$ per annum is the least growing sector (Obinna, 2012). In addition, the agriculture industry which is largely dominated by Small and Medium Enterprises is faced with problems ranging from greater consumer preference for imported foodstuffs, outdated farming methods, poor management and inadequate entrepreneurial capacity.

According to Sanusi (2003) the failure of many of such small and medium scale enterprises has been traced to factors beyond lack of long-term financing, extending to insufficient management skill and poor entrepreneurial capacity. In the ongoing transitional programme it is mandatory that entrepreneurs themselves begin to mobilize resources and internal strengths to strategically path ways to create and deliver value (Ardichvili, Cardozo and Ray, 2003). Barney's (1991) arguments about the resource based view can be summarized as improving and sustaining firm competitiveness through the engagement of firm unique resources and characteristics.

This research focus is to discuss the antecedents of business level strategies on agro-based firms 
in Nigeria. The scope of this research covers selected internal factors such as the critical decisions of top management, the organizational system, and degree of connectivity among departments.

\section{INTERNAL ORGANIZATIONAL FACTORS THAT INFLUENCE BUSINESS LEVEL STRATEGIES}

Strategic orientation as a concept has gained wide research attention in the field of strategic management (e.g. Aragón-Sánchez and Sánchez-Marín, 2005; Slater, Olson, and Hult, 2006; Choy and Mula, 2008; Liu and Fu, 2011), and as an interdisciplinary concept involving entrepreneurial orientation, marketing orientation and learning orientation (e.g. Zhou, Yim and Tse, 2005; Arguelles and Bautista, 2007). Strategic orientation includes various traits that describe an organization's strategic behaviours, management perceptions and responses to its environment. Strategic orientation has a strong internal inclination to the firm since it forms part of its capability, its belief and values towards achieving superior performance (Zhou, Yim and Tse, 2005).

\section{Top Management Factor}

The effective formulation and implementation of any organizational strategy largely depends on organizational leadership. Strategic decision making within an organizational system is a task which top management always must deal with (Richter and Schmidt, 2005). According to Meyer (2009), top management shape strategic patterns in the organization through competencies, experiences and mental conceptualizations. In a study that investigated the effects of Strategy and the Information-Processing Structure of Top Management Teams, Thomas and McDaniels (1990) asserted that very often the perception of the top management team about strategic issues facing the firm determines the strategic behaviour of the organization. Although heterogeneous top management characteristics has been identified to influence competitive behaviours and strategic decision postures of the firm (Hambrick, Cho, and Cheng, 1996; Krivogorsky and Eichenseher, 2005), organizational leadership across all levels of the firm impacts on effective implementation of strategic initiatives (O’Reilly, Caldwell, Chatman, Lapiz and Self, 2010). Studying the influence of top management teams and organizational strategic postures, Levy (2005) asserted that top management's cognitive processes about its external environment determine the strategic postures of the organization. But, it has also been argued that strategic patterns operational in a firm are more internally induced based on perception and interpretations of the firm's culture to its dynamic environment (Johnson, 1992).

\section{Organizational System}

In the view of the American Public Human Services Association (2012) a typical Organizational System model consists of a series of interconnected and changing parts of the organizational system. These include strategy, inputs, performance capacity, action to drive performance, output, outcomes, and feedback data. These parts work together to form a balance that helps organizations achieve effectiveness. It also suggests that the effectiveness of any strategy will largely depend on the degree to which internal organizational staff and external stakeholders perceive it 
as being important to the organization (APHSA, 2012). The RBL Group (2013) also expounded the system framework of the organization to include a complex of structure, processes, people and reward systems working together to implement strategies and improve performance of the organization. This is the overall aim of organizational design (McKnight and Kaney, 2010). Miles, Snow, Meyer and Coleman (1978) supported the fact that structure and processes are mechanisms which effective organizations build to achieve their strategies. Other authors and researchers have also supported this position, for example, Lewis (2001); Galbraith (2002); and Li, Guohui, and Eppler (2008).

\section{Departmental Connectivity}

Departmental connectivity explains the interrelatedness of activities and members of different units of the same organization. Meaningful interfunctional relationships are motivated by the desire to achieve broad organizational goals while at the same time accomplishing individual departmental objectives (Ruekert and Walker, 1987). This thinking is wholly captured in the systems view of the organization. The systems theory views the organization as a social network of interactions among functional units and activities with a drive to achieve a common goal (Friedman and Allen, 2010). Laszlo and Krippner (1998) argued that the relationship among system components (units or departments) concentrate on "the dynamics that define the characteristic functions, properties, and relationships that are internal or external to the system". According to Weick and Roberts (1993), this interactive process is known as the "collective mind" in which knowledge from all sources of the organization is networked and integrated to set a strategic pattern in the organization. Also, Willem and Scarbrough (2002) observed that knowledge sharing is an effective means of penetrating the borders of units within organizations.

\section{BUSINESS LEVEL STRATEGIC POSTURES}

Venkatraman (1989) proposed a set of strategic orientation variables that are applicable at the business level. They are: aggressiveness, analysis, defensiveness, futurity, proactiveness, and riskiness. Aggressiveness dimension measures the business ability to engage organizational resources in the pursuit of increased market share as a means to achieving business unit profitability. It can take the form of aggressive marketing (Ahlander, Cogley, Robbins and Wangler, 2009), price skimming, aggressive efforts towards being the overall cost leader, innovation strategies and differentiation. Analysis reflects the problem-solving orientation of the firm, its ability to develop solution alternatives and select the best alternative. It relates to the maintenance of internal consistency in the resource allocation strategies towards the achievement of corporate objectives. Defensiveness reflects the firm's emphasis to defend its core technology and product-market domain. According to Roberts (2005), strong brand image and positive customer perception of the firm are defensive strategies. Organizations often attempt to either secure market boundaries from new entrants or stiffen competition in the industry thereby making it difficult for competitors to operate effectively (Yannopoulos, 2011). Examples include entry deterring price and predatory pricing (Uslay, 2005). Futurity is the extent to which decisions that relate to possible future occurrences are seriously engaged. It reflects issues like sales forecast, possible changes in customer preference, and tracking of environmental changes. It is manifested by a 
firm's incorporation of its vision as a strategic concern (Stambaugh et al, 2011). Proactiveness reflects the firm's constant engagement in the search for new market opportunities, the first mover in the introduction of new products, while old products are strategically withdrawn from markets. It shows the degree of the firm's experimentation with marketing research responses (Venkatraman, 1989). It explains a firm's drive for first mover position in the market (Chang et al, 2002), the ability to take initiatives over environmental situations and the pursuit of new markets through the engagement of value innovations. Riskiness captures the extent of riskiness of the firm. This is reflected in its choice and criteria over resource allocation decisions and the general pattern of decision making. Firms characterized with high risk strategies may be tradingoff with lower profits than expected (Söderbom, 2012).

The justification for adopting the STROBE dimension introduced by Venkatraman (1989) is contained in the fact that unlike other dimensions that basically classify strategy, STROBE view strategic orientation along specific dimensions which are common to all firms (Morgan and Strong, 2003).

\section{METHODS}

The research made use of the descriptive survey research design. A sample size of 210 agro-based firms was surveyed of an estimated 1500 registered agro based firms in Lagos and Ogun States. Samples were selected using the convenience sampling technique and the purposive sampling. This approach was adopted because of respondents' unwillingness to supply information as required in the research instrument, therefore leading to selection of respondents who are willing to respond. A major strength of this sampling approach is the likelihood of obtaining unbiased responses from respondents since they willingly accepted the interview. The choice of the study area was largely influenced by cost of survey, time, logistic problems and accessibility. Therefore, the study area was chosen by purposive sampling method. Furthermore, the sampled firms were also chosen on similar premise: access and data availability. This sampling procedure make for a realistic pursuit of required information and information-rich respondents.

However, sampling within the organization involved the use of stratified sampling approach as well as purposive sampling. In each of the sampled organization the top hierarchies form a stratum which was purposefully sampled to include key organization officers. This is due to the fact that strategic issues demand the attention of well-trained officers which are usually located at the top echelon within the organization. Low cadre officers, below the rank of manager were excluded from the sample.

Data used for this study was obtained from both primary and secondary sources. The primary sources include the administration of questionnaires on: Managing Directors, Chief Executive Officers and Functional Managers of Agro-based firms in Lagos and Ogun States, while secondary source of data included Library, Internet facilities, text books, journals and conference papers. Most of the items in the questionnaire were adopted from the instrument developed by Venkatraman (1989), with modifications to suit the current need and industry of the study.

The research instrument was organized into three sections, A - C. Section A contain the background information of the respondents. This was designed to capture the respondent's status, 
demographic information and eligibility to respond to the questions. Section B focused on questions that are firm specific. It is focused on obtaining information relating to the characteristics and operations of the firm. It basically inquired into the date the company started operations and the number of employee presently serving in the organization. Section $C$ dealt with questions that relate to the thrust of the study. The section is divided into two parts. The first section attempt to gain insight into the strategic orientations of the firms. Therefore, questions were focused on the basic orientations of aggressiveness, analysis, defensiveness, futurity, proactiveness, and riskiness (Venkatraman, 1989). Each of these were scaled using a 5-point likert scale. The second segment focused questions on the performance variables. Following the works of Wang, Chich-Jen, and Mei-Ling (2010), three variables were adopted: Financial, business, and effectiveness dimensions of performance.

\subsection{Research Question}

The following research questions were formulated to reflect the relational impact of antecedents factors of strategic orientation.

1. How does organizational system impact on strategic orientation?

2. To what extent does top management significantly impact on firm strategic orientation?

3. In what ways does any relationship exist between strategic orientation and departmental connectivity?

\subsection{Research Hypotheses}

From the arguments above, the following hypotheses were formulated and as depicted in figure 1 below:

$\mathrm{H}_{1}$ : Organizational system does impact on Strategic orientation

$\mathrm{H}_{2}$ : Top management significantly impact on firm strategic orientation dimensions

$\mathrm{H}_{3}$ : There is a significant relationship between strategic orientation dimensions and departmental connectivity

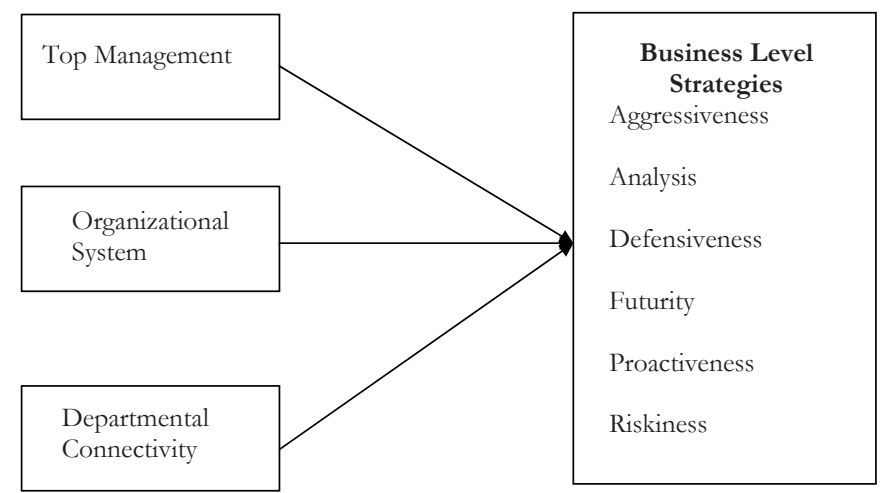

Fig. 1 - Internal factors that Influence Strategic Orientation Dimensions. Source: author. 


\section{ANALYSIS AND RESULTS}

A total of 193 questionnaires was retrieved and adjudged suitable, which formed the basis of the analysis in this study, representing 91.9 percent response rate. An analysis of the questionnaires by total responses showed that Lagos has the higher response rate of 122 (63.2\%). This could be a result of the concentration of most agri-business firms in strategic locations of the state, thereby forming a structured and organized pattern of operation and easy accessibility. Ogun has $71(36.8 \%)$. In addition, 50 respondents, that is $25.9 \%$ have less than 5 years working experience. $67(34.7 \%)$ obtain between 5 to 10 years working experience, while $29(15.0 \%)$ have experienced 11 to 15 years of working in the agricultural business. 47 (24.4\%) have worked in the business for 16 years and above. The largest number of respondents are those who are Managers in the organization, consisting of 96 of the respondents (49.7\%). 24 respondents $(12.4 \%)$ occupy positions of Chairman/M.D., while only 14 respondents (7.3\%) are CEO/Deputy M.D. Senior managerial position consists of 59 respondents (30.6\%). 170 respondents, that is $88.2 \%$ have a minimum of first degree while only 23 respondents $(11.9 \%)$ have less than first degree. This reveals that apart from experience gathered on the job a large number of respondents attained reasonable level of education to respond to the questionnaire. A large number of 108 firms, that is, $56.1 \%$ of the firms started before the year 2000. This reveals that majority of the firms are well established in the agricultural business. The remaining 85 firms (44.0\%) have existed from 2000 to date. 179 respondents $(92.7 \%)$ work in organizations with staff capacity of between 1 and 299 . This shows that most firms in the agro-based business are small and medium enterprises. Only 14 respondents $(7.3 \%)$ work in organizations with 300 and above staff capacity.

Tab. 1 - Zero-Order Correlation Co-efficient of Organizational System on Strategic Orientation. Source: Field Survey.

\begin{tabular}{|l|c|c|c|c|c|c|c|}
\hline & 1 & 2 & 3 & 4 & 5 & 6 & 7 \\
\hline Aggressiveness & 1 & & & & & & \\
\hline Analysis & $.385^{* *}$ & 1 & & & & & \\
\hline Defensiveness & $.303^{* *}$ & $.559^{* *}$ & 1 & & & & \\
\hline Futurity & $.443^{* *}$ & $.621^{* *}$ & $.456^{* *}$ & 1 & & & \\
\hline Proactiveness & $.444^{* *}$ & $.330^{* *}$ & $.314^{* *}$ & $.578^{* *}$ & 1 & & \\
\hline Riskiness & -.071 & $-.184^{*}$ & $-.166^{*}$ & $-.274^{* *}$ & -.124 & 1 & \\
\hline OrgSystem & $-.201^{* *}$ & $-.361^{* *}$ & $-.298^{* *}$ & $-.245^{* *}$ & -.043 & $.380^{* *}$ & 1 \\
\hline
\end{tabular}

** Correlation is significant at the 0.01 level (2-tailed).

* Correlation is significant at the 0.05 level (2-tailed).

Table 1 shows the correlation relationships among the business level strategies and organizational system. The result reveals that all dimensions of strategic orientation have a relationship with one another except riskiness dimension. The table also reveals that organizational system correlate with all six dimensions of strategic orientation except proactiveness: aggressiveness $(\mathrm{r}=$ $-0.2, \mathrm{p}<0.05)$; analysis $(\mathrm{r}=-0.36, \mathrm{p}<0.05)$; defensiveness $(\mathrm{r}=-0.29, \mathrm{p}<0.05)$; futurity $(\mathrm{r}=-0.24$, $\mathrm{p}<0.05)$ and riskiness $(\mathrm{r}=0.38, \mathrm{p}<0.05)$. 
Tab. 2 - Zero-Order Correlation Co-efficient of Top Management Factor and Strategic Orientation Dimension. Source: Field Survey.

\begin{tabular}{|l|c|c|c|c|c|c|c|}
\hline & 1 & 2 & 3 & 4 & 5 & 6 & 7 \\
\hline Aggressiveness & 1 & & & & & & \\
\hline Analysis & $.385^{* *}$ & 1 & & & & & \\
\hline Defensiveness & $.303^{* *}$ & $.559^{* *}$ & 1 & & & & \\
\hline Futurity & $.443^{* *}$ & $.621^{* *}$ & $.456^{* *}$ & 1 & & & \\
\hline Proactiveness & $.444^{* *}$ & $.330^{* *}$ & $.314^{* *}$ & $.578^{* *}$ & 1 & & \\
\hline Riskiness & -.071 & $-.184^{*}$ & $-.166^{*}$ & $-.274^{* *}$ & -.124 & 1 & \\
\hline TopMgtFactor & $.327^{* *}$ & $.389^{* *}$ & $.397^{* *}$ & $.348^{* *}$ & $.176^{*}$ & .010 & 1 \\
\hline
\end{tabular}

** Correlation is significant at the 0.01 level (2-tailed).

* Correlation is significant at the 0.05 level (2-tailed).

Table 2 shows the correlation relationships among top management factor and strategic orientation dimension. The result reveals that all dimensions of strategic orientation have a relationship with one another except riskiness dimension. The table also reveals that top management factor correlate with all six dimensions of strategic orientation except riskiness aggressiveness $(r=0.3$, $\mathrm{p}<0.01)$; analysis $(\mathrm{r}=0.38, \mathrm{p}<0.01)$; defensiveness $(\mathrm{r}=0.39, \mathrm{p}<0.01)$; futurity $(\mathrm{r}=0.34, \mathrm{p}<0.01)$ and proactiveness $(\mathrm{r}=0.17, \mathrm{p}<0.05)$. This means that whereas top management perception significantly impacts on the degree to which the firm manifests aggressiveness, traits of analysis, defensiveness, futurity and proactiveness, the traits of riskiness of the enterprise will depend on other factors other than top management factor.

Tab. 3 - Zero-Order Correlation Co-efficient of Strategic Orientation Dimension and Departmental Connectivity. Source: Field Survey.

\begin{tabular}{|c|c|c|c|c|c|c|c|}
\hline & 1 & 2 & 3 & 4 & 5 & 6 & 7 \\
\hline Aggressiveness & 1 & & & & & & \\
\hline Analysis & $.385^{* *}$ & 1 & & & & & \\
\hline Defensiveness & $.303^{* *}$ & $.559^{* *}$ & 1 & & & & \\
\hline Futurity & $.443^{* *}$ & $.621^{* *}$ & $.456^{* *}$ & 1 & & & \\
\hline Proactiveness & $.444^{* *}$ & $.330^{* *}$ & $.314^{* *}$ & $.578^{* *}$ & 1 & & \\
\hline Riskiness & -.071 & $-.184^{*}$ & $-.166^{*}$ & $-.274^{* *}$ & -.124 & 1 & \\
\hline DeptConnectivity & $.162^{*}$ & .120 & -.024 & $.261^{* *}$ & $.170^{*}$ & $.161^{*}$ & 1 \\
\hline
\end{tabular}

** Correlation is significant at the 0.01 level (2-tailed).

* Correlation is significant at the 0.05 level (2-tailed).

Table 3 summarizes the interconnecting relationship between departmental connectivity and strategic orientation dimensions. There is a significant positive relationship between departmental connectivity and strategic orientation except at the analysis and defensiveness orientations: aggressiveness $(\mathrm{r}=0.16, \mathrm{p}<0.05)$; futurity $(\mathrm{r}=0.26, \mathrm{p}<0.01)$ proactiveness $(\mathrm{r}=0.17, \mathrm{p}<0.05)$ and riskiness $(\mathrm{r}=0.16, \mathrm{p}<0.05)$. It means that departmental connectivity will not necessarily enhance a problem solving and domain defense approach to strategy. 
Tab. 4 - Impact of Organizational System, Top Management Factor, and Departmental Connectivity on Aggressiveness and Analysis Dimensions. Source: Field Survey.

\begin{tabular}{|c|c|c|c|c|c|c|c|c|c|c|}
\hline & \multicolumn{5}{|c|}{ Aggressiveness } & \multicolumn{5}{|c|}{ Analysis } \\
\hline & \multicolumn{2}{|c|}{$\begin{array}{l}\text { Unstd. } \\
\text { Coefficient }\end{array}$} & \multirow{2}{*}{$\begin{array}{l}\text { Std } \\
\text { Co- } \\
\text { eff. } \\
\text { B }\end{array}$} & \multirow[b]{2}{*}{$\mathrm{T}$} & & \multicolumn{2}{|c|}{$\begin{array}{l}\text { Unstd. } \\
\text { Coefficient }\end{array}$} & \multirow{2}{*}{$\begin{array}{l}\text { Std } \\
\text { Co- } \\
\text { eff. } \\
\text { B }\end{array}$} & \multirow[b]{2}{*}{$\mathrm{T}$} & \\
\hline & B & $\begin{array}{l}\text { Std } \\
\text { Error }\end{array}$ & & & & B & $\begin{array}{l}\text { Std } \\
\text { Error }\end{array}$ & & & \\
\hline $\begin{array}{l}\text { Organi- } \\
\text { zational } \\
\text { System }\end{array}$ & -.177 & .064 & -.193 & $-2.749 *$ & .007 & 3.411 & .261 & & $13.055^{*}$ & .000 \\
\hline $\begin{array}{l}\text { Top Mgt } \\
\text { Factor }\end{array}$ & .423 & .108 & .270 & $3.913 *$ & .000 & -.163 & .031 & -.344 & $-5.246^{*}$ & .000 \\
\hline $\begin{array}{l}\text { Dept. } \\
\text { Connec- } \\
\text { tivity }\end{array}$ & .220 & .091 & .168 & $2.406^{*}$ & .017 & .250 & .052 & .309 & $4.782 * *$ & .018 \\
\hline $\mathrm{R}$ & 0.39 & & & & & 0.51 & & & & \\
\hline $\mathrm{R}^{2}$ & 0.15 & & & & & 0.26 & & & & \\
\hline Adj. $\mathrm{R}^{2}$ & 0.141 & & & & & 0.251 & & & & \\
\hline $\mathrm{F}$ & 11.511 & & & & & 22.48 & & & & \\
\hline
\end{tabular}

$\left.\left.\left({ }^{*} \mathrm{p}<0.01\right) * * \mathrm{p}<0.05\right) * * * \mathrm{p}<0.1\right)$

Table 4 shows the impact of organizational system, top management factor, and departmental connectivity on aggressiveness and analysis dimensions of strategic orientation. All three factors are significant determinants of firms adopting both the aggressiveness and analysis dimensions. At $\mathrm{r}^{2}=0.15$ and $\mathrm{r}^{2}=0.26$ organizational system, top management factor, and departmental connectivity fitly explains for change in aggressiveness and analysis dimensions respectively. It is also revealed that while organizational system has a negative impact on aggressiveness dimension, top management factor has a negative effect on analysis dimension.

Tab. 5 - Impact of Organizational System, Top Management Factor, and Departmental Connectivity on Defensiveness and Futurity Dimensions. Source: Field Survey.

\begin{tabular}{|c|c|c|c|c|c|c|c|c|c|c|}
\hline & \multicolumn{5}{|c|}{ Defensiveness } & \multicolumn{5}{|c|}{ Futurity } \\
\hline & \multicolumn{2}{|c|}{$\begin{array}{l}\text { Unstd. } \\
\text { Coefficient }\end{array}$} & \multirow{2}{*}{$\begin{array}{l}\text { Std. } \\
\text { Coeff. } \\
\beta\end{array}$} & \multirow[b]{2}{*}{$\mathrm{T}$} & & \multicolumn{2}{|c|}{$\begin{array}{l}\text { Unstd. } \\
\text { Coefficient }\end{array}$} & \multirow{2}{*}{$\begin{array}{l}\text { Std } \\
\text { Coeff. } \\
\text { B }\end{array}$} & \multirow[b]{2}{*}{$\mathrm{T}$} & \\
\hline & B & $\begin{array}{l}\text { Std } \\
\text { Error }\end{array}$ & & & & B & $\begin{array}{l}\text { Std } \\
\text { Error }\end{array}$ & & & \\
\hline $\begin{array}{l}\text { Organi- } \\
\text { zational } \\
\text { System }\end{array}$ & -.139 & .041 & -.231 & $-3.408^{*}$ & .001 & -.174 & .044 & -.266 & $-3.966^{*}$ & .000 \\
\hline
\end{tabular}




\begin{tabular}{|c|c|c|c|c|c|c|c|c|c|c|}
\hline $\begin{array}{l}\text { Top Mgt } \\
\text { Factor }\end{array}$ & .373 & .069 & .361 & $5.417 *$ & .000 & .294 & .074 & .263 & $3.985^{*}$ & .000 \\
\hline $\begin{array}{l}\text { Dept. } \\
\text { Connec- } \\
\text { tivity }\end{array}$ & -.018 & .058 & -.022 & -.319 & .750 & .266 & .062 & .285 & $4.276^{*}$ & .000 \\
\hline $\mathrm{R}$ & \multicolumn{5}{|l|}{0.46} & \multicolumn{5}{|l|}{0.48} \\
\hline $\mathrm{R}^{2}$ & \multicolumn{5}{|l|}{0.21} & \multicolumn{5}{|l|}{0.23} \\
\hline Adj. $\mathrm{R}^{2}$ & \multicolumn{5}{|c|}{0.200} & \multicolumn{5}{|c|}{0.219} \\
\hline $\mathrm{F}$ & \multicolumn{5}{|c|}{ 17.039* } & \multicolumn{5}{|c|}{ 18.936* } \\
\hline
\end{tabular}

$\left.\left.\left({ }^{*} \mathrm{p}<0.01\right) * * \mathrm{p}<0.05\right) * * * \mathrm{p}<0.1\right)$

Table 5 shows the impact of organizational system, top management factor, and departmental connectivity on defensiveness and futurity dimensions of strategic orientation. Collectively all three independent variables reveal 17.039 and 18.936 degree of impact on defensiveness and futurity dimensions respectively. Organizational system (with a negative relationship) and top management factor (with a positive relationship) correlates with aggressiveness. Futurity dimension is positively affected by all three factors. At $\mathrm{r}^{2}=0.21$ and $\mathrm{r}^{2}=0.23$ organizational system, top management factor, and departmental connectivity explain the degree of change in defensiveness and futurity respectively.

Tab. 6 - Impact of Organizational System, Top Management Factor, and Departmental Connectivity on Proactiveness and Riskiness Dimensions. Source: Field Survey.

\begin{tabular}{|c|c|c|c|c|c|c|c|c|c|c|}
\hline & \multicolumn{5}{|c|}{ Proactiveness } & \multicolumn{5}{|c|}{ Riskiness } \\
\hline & \multicolumn{2}{|c|}{$\begin{array}{l}\text { Unstd. } \\
\text { Coefficient }\end{array}$} & \multirow{2}{*}{$\begin{array}{l}\begin{array}{l}\text { Std. } \\
\text { Coeff. }\end{array} \\
\text { B }\end{array}$} & \multirow[b]{2}{*}{$\mathrm{T}$} & & \multicolumn{2}{|c|}{$\begin{array}{l}\text { Unstd. } \\
\text { Coefficient }\end{array}$} & \multirow{2}{*}{$\begin{array}{l}\text { Std } \\
\text { Coeff. } \\
\text { B }\end{array}$} & \multirow[b]{2}{*}{$\mathrm{T}$} & \multirow[b]{3}{*}{.000} \\
\hline & B & $\begin{array}{l}\text { Std } \\
\text { Error }\end{array}$ & & & & $\beta$ & $\begin{array}{l}\text { Std } \\
\text { Error }\end{array}$ & & & \\
\hline $\begin{array}{l}\text { Organi- } \\
\text { zational } \\
\text { System }\end{array}$ & -.045 & .060 & -.056 & -.747 & .456 & .291 & .054 & .376 & $5.355^{*}$ & \\
\hline $\begin{array}{l}\text { Top Mgt } \\
\text { Factor }\end{array}$ & .197 & .100 & .144 & $1.964^{* *}$ & .051 & .086 & .091 & .065 & .943 & .347 \\
\hline $\begin{array}{l}\text { Dept. Con- } \\
\text { nectivity }\end{array}$ & .185 & .084 & .162 & $2.195^{* *}$ & .029 & .072 & .077 & .065 & .934 & .351 \\
\hline $\mathrm{R}$ & \multicolumn{5}{|l|}{0.23} & \multicolumn{5}{|l|}{0.39} \\
\hline $\mathrm{R}^{2}$ & \multicolumn{5}{|l|}{0.05} & \multicolumn{5}{|l|}{0.15} \\
\hline Adj. $\mathrm{R}^{2}$ & \multicolumn{5}{|c|}{0.040} & \multicolumn{5}{|c|}{0.141} \\
\hline $\mathrm{F}$ & \multicolumn{5}{|c|}{$3.679 * * *$} & \multicolumn{5}{|c|}{$11.508^{* *}$} \\
\hline
\end{tabular}

$(* \mathrm{p}<0.01) * * \mathrm{p}<0.05) * * * \mathrm{p}<0.1)$ 
Table 6 shows the impact of organizational system, top management factor, and departmental connectivity on proactiveness and riskiness dimensions of strategic orientation. Collectively all three independent variables reveal 3.679 and 11.508 degree of impact on proactiveness and riskiness dimensions respectively. Top management factor and departmental connectivity positively correlates with proactiveness dimension. Organizational system positively correlates with riskiness. At $\mathrm{r}^{2}=0.05$ top management and departmental connectivity explain for the degree of fitness with proactiveness dimension. At $\mathrm{r}^{2}=0.15$ organizational system explain for the degree of fitness with riskiness dimension.

\section{DISCUSSSION}

The thinking about organizations as systems involves several parts working together for the accomplishment of a common goal. Therefore emphasis is placed on the importance of every part of the system (American Public Human Services Association, 2012). Humans are identified as the most important resource of the organization and are considered to be the basic engine to running every successful system (Montana and Charnov, 1993). The results found by this research suggest that organizational systems are effectively coordinated and controlled by top management or at least supervisors. Zaharov (2010) shared the view that the formation of organizational hierarchies flow along the combination of standardization and control continuums. Also, the correlation and regression analysis statistically computed to test for the effectiveness of relationship between strategic orientation and top management factor revealed a positive outcome. This finding is in line with the position of existing research such as Thomas and Ramaswamy (1996) who suggested that an alignment of managerial characteristics and strategic direction result in better organizational performance. Results computed shows that aggressiveness, futurity, proactiveness, and riskiness dimensions significantly correlate with departmental connectivity. Also, in the regression tables it was observed that aggressiveness, analysis, futurity, and proactiveness dimensions are significantly affected by top management factor. The finding of this hypothesis might result from the fact that most organizations in the agro-business industry are small and medium enterprises that have simple organizational structures. This makes coordination effective and flexible (Rijn, 2004).

\section{CONCLUSION}

The findings of this study show the importance of specific factors to strategies that support successful business performance. The adoption of Strategic orientation by an enterprise depends on antecedent factors, among which are: top management factor, organizational system, and departmental connectivity. Top management disposition to strategic orientation greatly impacts on the success or failure of such strategic activities. The support for strategies can take the form of designing policies and programmes that will achieve the proper implementation and control of chosen strategies. It is equally important for managers to understand that their commitment to the aggressive, analysis, defensive, futurity, proactive, and risk-taking behaviours of business processes can establish a culture within employees and the entire organizational system. Organizations are considered to exist as a system that consists of many different components working 
together to achieve common objectives. The ability of management to ensure that all departments across the organization work together with a chosen strategic orientation will present the beauty in the system view of the organization and can better enhance performance.

\section{References}

1. Ahlander, T., Cogley, K., Robbins, K., \& Wangler, K. (2009). Aggressive Marketing. Retrieved 26 June, 2014, from http://www7.svsu.edu/ kdwangle/Aggressive\%20Marketing.pdf

2. American Public Human Service Association (2012). Organizational Effectiveness, A guidebook for Building Organizational Effectiveness Capacity: A Training System Example. Washington DC

3. Aragón-Sánchez, A., \& Sánchez-Marín, G. (2005). Strategic Orientation, Management Characteristics, and Performance: A Study of Spanish SMEs. Journal of Small Business Management, 43 (3), 287-308. http://dx.doi.org/10.1111/j.1540-627X.2005.00138.x

4. Ardichvili, A., Cardozo, R., \& Ray, S. (2003). A theory of entrepreneurial opportunity identification and development. Journal of Bussiness Venturing, 18(1) 105-123. http://dx.doi. org/10.1016/S0883-9026(01)00068-4

5. Arguelles, R., \& Bautista, R. (2007). Strategic Orientation of Small Business Entrepreneurs in Baguio City. A paper presented at the 10th National Convention on Statistics (NCS). EDSA Shangri-La Hotel, October 1-2, 2007.

6. Barney, J. (1991). Firm Resources and Sustained Competitive Advantage. Journal of Management, 17(1), 99-120. http://dx.doi.org/10.1177/014920639101700108

7. Chang, S. C., Lin, N. P., Wea, C. L., \& Sheu, C. (2002). Aligning manufacturing strategy with business strategy — an empirical study in high-tech industry. International Journal of Technology Management, 24(1), 70-87. http://dx.doi.org/10.1504/IJTM.2002.003045

8. Choy, S. M., \& Mula, J. M. (2008). The impact of strategic orientation dimensions on business performance: a case study based on an international organisation. In: ANZAM 2008: Managing in the Pacific Century, 2-5 Dec 2008, Auckland, New Zealand.

9. Friedman, B., \& Allen, K. N. (2010). System theory. In J. Brandell, Theory and Practice in Clinical Social Work, pp. 3-20, Thousand Oaks, CA: Sage Publications, Inc.

10. Galbraith, J. R. (2002). Organizing to Deliver Solution. Organizational Dynamics, 31(2), 194207. http://dx.doi.org/10.1016/S0090-2616(02)00101-8

11. Hambrick, D. Cho, T., \& Chen, M. (1996). The Influence of Top Management Team Heterogeneity on Firms' Competitive Moves. Administrative Science Quarterly, 41(4), 659-684. http://dx.doi.org/10.2307/2393871

12. Johnson, G. (1992). Managing Strategic Change Strategy, Culture and Action. Long Range Planning, 25(1), 28-36. http://dx.doi.org/10.1016/0024-6301(92)90307-N

13. Krivogorsky, V., \& Eichenseher, J. (2005). Effects of Top Management Replacement on Firms' Behavior: Empirical Analysis of Russian Companies. MIR: Management International Review, 45(4), 437-458. 
14. Laszlo, A., \& Krippner, S. (1998). Systems Theories: Their origins, foundations, and development. In Jordan, J. C. (Ed.), Systems Theories and A Priori Aspects of Perception, Advances in Psychology (Vol. 126, pp. 47-74). Amsterdam: North-Holland/Elsevier. http://dx.doi. org/10.1016/S0166-4115(98)80017-4

15. Levy, O. (2005). The Influence of Top Management Team Attention Patterns on Global Strategic Posture of Firms. Journal of Organizational Behavior, 26(7), 797-819. http://dx.doi. org/10.1002/job.340

16. Lewis, P. (2001). Chapter 4 - Reward Management', In Contemporary Human Resource Management. In Redman, T., \& Wilkinson, A. (Eds.), Pearson Education (pp. 98-127).

17. Li, Y., Guohui, S., \& Eppler, M. J. (2008). Making Strategy Work: A Literature Review on the Factors Influencing Strategy Implementation. ICA Working Paper, 2/2008, 1-46.

18. Liu, B., \& Fu, Z. (2011). Relationship between Strategic Orientation and Organizational Performance in Born Global: A Critical Review. International Journal of Business and Management, 6(3), 109-115. http://dx.doi.org/10.5539/ijbm.v6n3p109

19. McKnight, R., \& Kaney, T. (2010). Organizational Design: Aligning Structure, Business Processes, and People Systems With the Strategy. Retrieved June 23, 2014, from http://mcknightkaney. com/Design_Your_Organization_files/2\%20Strategy\%20ORG\%20DESIGN.pdf

20. Meyer, K. E. (2006). Corporate Strategies under Pressures of Globalization: Globalfocusing. University of Bath, School of Management. Working Paper Series. Retrieved from: http://www.bath. ac.uk/management/research/papers.htm

21. Miles, R. E., Snow, C. C., Meyer, A. D., \& Coleman, H. J. (1978). Organizational Strategy, Structure, and Process. The Academy of Management Review, 3(3), 546-562. http://dx.doi. $\operatorname{org} / 10.2307 / 257544$

22. Montana, P., \& Charnov, B. (1993). Management: A Streamlined Course for Students and Business People (pp. 155-169). New York: Hauppauge..

23. Morgan, R., \& Strong, C. (2003). Business performance and dimensions of strategic orientation. Journal of Business Research, 56(3), 163-176. http://dx.doi.org/10.1016/S01482963(01)00218-1

24. Obinna C. (2012). NIRS AL: Unlocking Nigeria's Agricultural Potentials. Retrived from http:// www.thisdaylive.com/articles/nirsal-unlocking-nigeria-s-agricultural potentials/117865

25. O'Reilly, C. A., Caldwell, D. F., Chatman, J. A., Lapiz, M., \& Self, W. (2010). How leadership matters: The effects of leaders' alignment on strategy implementation. The Leadership Quarterly, 21(1), 104-113. http://dx.doi.org/10.1016/j.leaqua.2009.10.008

26. RBL Group. (2013). The Organizational Systems Model: A Tool for Developing High Performance. Retrieved June 23, 2014, from https://rblip.s3.amazonaws.com/Articles/Organizational $\% 2$ 0Systems\%20Model\%20-\%20Dave\%20Hanna.pdf

27. Richter, A., \& Schmidt, S. (2005). How Does Strategy Process Influence Strategy Content? Antecedents Of Consistency Between Resource Allocation Decisions And Corporate Strategy. Schmalenbach Business Review, 57(4), 332-350.

28. Rijn, J. (2004). Designing Organisation Structures. Retrieved from http://www.indevelopment. $\mathrm{nl} /$ PDFfiles/organisationStructure.pdf 
29. Robert, J. H. (2005). Defensive Marketing How a Strong Incumbent Can Protect Its Position. Harvard Business Review, 83(11), 150-157.

30. Ruekert, R. W., \& Walker, O. C. (1987). Marketing's Interaction With Other Functional Units: A Conceptual Framework and Empirical Evidence. Journal of Marketing, 51(1), 1-19. http://dx.doi.org/10.2307/1251140

31. Sanusi, J. (2003). Overview of Government's Efforts in the Development of SMEs and the Emergence of Small and Medium Industries Equity Investment Scheme (SMIEIS), Presented at the National Summit on SMIEIS Organized by the Bankers' Committee and Lagos Chambers of Commerce and Industry (LCCI), Lagos on 10th June, 2003.

32. Slater, S., Olson, E., \& Hult, T. (2006). The Moderating Influence Of Strategic Orientation On The Strategy Formation Capability - Performance Relationship. Strategic Management Journal, 27(12), 1221-1231. http://dx.doi.org/10.1002/smj.569

33. Söderbom, M. (2012). Managerial Risk. Attitudes and Firm Performance in Ghanaian Manufacturing: An Empirical Analysis Based on Experimental Data. CSAE-UNIDO Working Paper No. 3.

34. Stambaugh, J., Yu, A., \& Dubinsky, A. (2011). Before the Attack: A Typology of Strategies for Competitive Aggressiveness. Journal of Management Policy and Practice, 12(1), 49-63.

35. Thomas, J., \& McDaniel, R. (1990). Interpreting Strategic Issues: Effects of Strategy and the Information-Processing Structure of Top Management Teams. The Academy of Management Journal, 33(2), 286-306. http://dx.doi.org/10.2307/256326

36. Thomas, A., \& Ramaswamy, K. (1996). Matching Managers to Strategy: Further Tests to the Miles and Snow Typology. British Journal of Management, 7(3), 247-261. http://dx.doi. org/10.1111/j.1467-8551.1996.tb00118.x

37. Uslay, C. (2005). The Role Of Pricing Strategy In Market Defense. A dissertation of Georgia Institute of Technology, Georgia. Retrieved June 26, 2014, from https://smartech.gatech. edu/bitstream/handle/1853/10578/uslay_can_200505_phd.pdf;jsessionid=5B62245F59AA 7E184987D2C12B236DC6.smart2?sequence=1

38. Venkatraman, N. (1989). Strategic Orientation of Business Enterprises: The Construct, Dimensionality, and Measurement. Management Science, 35(8), 942-962. http://dx.doi. $\operatorname{org} / 10.1287 / \mathrm{mnsc} .35 .8 .942$

39. Weick, K. E., \& Roberts, K. H. (1993). Collective Mind in Organizations: Heedful Interrelating on Flight Decks. Administrative Science Quarterly, 38(3), 357-381. http://dx.doi. org $/ 10.2307 / 2393372$

40. Willem, A., \& Scarbrough, H. (2002). Structural Effects on Inter-Unit Knowledge Sharing: The Role of Coordination Under Different Knowledge Sharing. Paper Submitted to the Third European Conference on Organizational Knowledge, Learning, and Capabilities, 5-6 April 2002, Athens.

41. Yannopoulos, P. (2011). Defensive and Offensive Strategies for Market Success. International Journal of Business and Social Science, 2(13), 1-12.

42. Zaharov, R. (2010). Organizational Structure Evaluation Mechanisms Based On Classification Features. In Proceedings of the 10th International Conference "Reliability and Statistics in Transportation and Communication” (pp. 317-326), 20-23 October 2010, Riga, Latvia. 
43. Zhou, K., Yim, C., \& Tse, D. (2005), The Effects of Strategic Orientations on Technologyand Market-Based Breakthrough Innovations, Journal of Marketing, 69(2), 42-60. http:// dx.doi.org/10.1509/jmkg.69.2.42.60756

\section{Contact information}

Ibidunni Ayodotun Stephen

Department of Business Management, Covenant University,

Km 10, Idiroko Road, P.M.B. 1023, Ota, Ogun State, Nigeria.

Email:ayodotun.ibidunni@covenantuniversity.edu.ng

Ogundana Oyebisi Mary

Department of Economics, Accounting and Finance, Bells University of Technology

Ota, Ogun State, Nigeria

Email:ogundanaoyebs@yahoo.com 